\title{
Synthesis of the Spirofungin B Core by a Reductive Cyclization Strategy
}

\author{
Thomas E. La Cruz and Scott D. Rychnovsky* \\ Department of Chemistry, 516 Rowland Hall, University of \\ California, Irvine
}

Irvine, California 92697-2025

srychnov@uci.edu

\section{Experimental}

General Experimental. IR spectra were recorded on a MIDAC Prospect FT-IR spectrometer. ${ }^{1} \mathrm{H}$ NMR spectra were recorded at $500 \mathrm{MHz}$ and ${ }^{13} \mathrm{C}$ NMR spectra were recorded at $125 \mathrm{MHz}$ on Bruker instruments. Chemical shifts of the ${ }^{1} \mathrm{H}$ NMR spectra were referenced to residual chloroform at $7.27 \mathrm{ppm}$, or benzene $(7.16 \mathrm{ppm})$. Chemical shifts of ${ }^{13} \mathrm{C}$ NMR spectra were referenced to $\mathrm{CDCl}_{3}$ at $77.0 \mathrm{ppm}$, or $\mathrm{C}_{6} \mathrm{D}_{6}(128.39 \mathrm{ppm})$. All coupling constants $(J)$ are reported in Hertz $(\mathrm{Hz})$. Optical rotations were determined on a JASCO DIP-370 digital polarimeter. Mass spectra were determined on an AE2-MS 30, a PG 7070E, a Fisions autospec spectrometer, or a Micromass LCT Electrospray spectrometer. Tetrahydrofuran (THF), $\mathrm{Et}_{2} \mathrm{O}$, and $\mathrm{CH}_{2} \mathrm{Cl}_{2}$ were dried by filtration through alumina according to the procedure described by Grubbs. ${ }^{1}$ Liquid chromatography was performed using forced flow (flash chromatography) of the indicated solvent system on EMD silica gel $60(40-60 \mu \mathrm{m})$. Deactivated silica gel refers to silica gel that was treated with $\mathrm{Et}_{3} \mathrm{~N}$, and then washed with the desired eluent. Moisture sensitive reactions were

\footnotetext{
${ }^{1}$ Pangborn, A. B.; Giardello, M. A.; Grubbs, R. H.; Rosen, R. K.; Timmers, F. J., Organometallics 1996, 15, 1518-1520.
} 
performed under an atmosphere of argon using flame, or oven dried glassware, and standard syringe/septa techniques. Reagents bought from Aldrich were used with no further purification. Cyano acetal $\mathbf{2 5}$ was dried by being dissolved in benzene $(1 \mathrm{~mL})$ and then concentrated under reduced pressure.

Preparation of a stock solution of LiDBB in THF (ca. 0.4 M). To a two-necked round-bottom flask equipped with a glass stir-bar was added 4,4'-di-tert-butylbiphenyl (DBB) $(0.747 \mathrm{~g}, 2.72 \mathrm{mmol})$, THF $(6.80 \mathrm{~mL})$, and the solution was stirred under argon. To the stirring solution of DBB was introduced $1.0 \mathrm{mg}$ 1,10-phenanthroline, the mixture was cooled to $0{ }^{\circ} \mathrm{C}$, and titrated with $n$ - $\mathrm{BuLi}(2.5 \mathrm{M}$ in hexanes, added to remove any residual trace of water) until a dark red end point persisted. Fresh lithium metal (0.226 g, $32.5 \mathrm{mmol}$ ) was prepared by submerging the wire in hexanes while scraping off the oxidized surface with an Exacto ${ }^{\circledR}$ knife. The shiny metal was then cut directly into the DBB solution under a stream of argon, forming a dark green color within 5 minutes. The resulting mixture was allowed to stir at $0{ }^{\circ} \mathrm{C}$ for 5 hours to form the desired LiDBB solution (ca. $0.4 \mathrm{M})$.

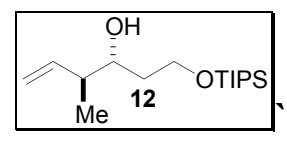

Homoallylic alcohol 12. Alcohol 12 was synthesized by following a published procedure. Dreher, S. D.; Leighton, J. L. J. Am. Chem Soc. 2001, 123, 341-342.

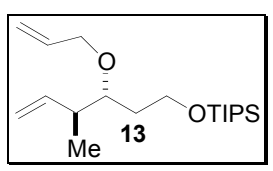

Allyl ether 13. Sodium hydride ( $60 \%$ dispersion in mineral oil, $1.68 \mathrm{~g}, 69.9 \mathrm{mmol}$ ) was washed with hexanes $(2 \times 10 \mathrm{~mL})$, and then $35 \mathrm{~mL}$ of DMF was introduced into the reaction vessel. The resulting slurry was cooled to $0{ }^{\circ} \mathrm{C}$ and then a solution of alcohol $\mathbf{1 2}$ 
$(2.00 \mathrm{~g}, 6.99 \mathrm{mmol})$ in $8 \mathrm{~mL}$ of DMF was added dropwise over a five minute period. The slurry was warmed to room temperature and stirred for $30 \mathrm{~min}$. Allyl bromide $(6.08 \mathrm{~mL}$, $69.9 \mathrm{mmol}$ ) was then added dropwise, and the resulting yellow mixture was stirred at room temperature for $3 \mathrm{hr}$. The mixture was cooled to $0{ }^{\circ} \mathrm{C}$, the excess $\mathrm{NaH}$ was quenched with $20 \mathrm{~mL}$ of saturated $\mathrm{NaHCO}_{3(\mathrm{aq})}$, the mixture was diluted with $\mathrm{H}_{2} \mathrm{O}$ (20 $\mathrm{mL})$ and extracted with $\mathrm{Et}_{2} \mathrm{O}(2 \times 100 \mathrm{~mL})$. The organic phase was washed with brine, dried over $\mathrm{MgSO}_{4}$, filtered and concentrated to give a residue that was purified by flash chromatography ( $3 \% \mathrm{Et}_{2} \mathrm{O} /$ Hexanes) to give $2.04 \mathrm{~g}$ ( $89 \%$ yield) of the title product as a colorless oil: $\mathrm{R}_{\mathrm{f}}=0.25\left(3 \% \mathrm{Et}_{2} \mathrm{O} /\right.$ Hexanes$) ;{ }^{1} \mathrm{H}$ NMR $\left(500 \mathrm{MHz}, \mathrm{CDCl}_{3}\right) \delta 5.93(\mathrm{~m} \mathrm{1H})$, $5.81(\mathrm{~m}, 1 \mathrm{H}), 5.26(\mathrm{~m} .1 \mathrm{H}), 5.13(\mathrm{~m}, 1 \mathrm{H}), 5.04(\mathrm{~m}, 2 \mathrm{H}), 4.03(\mathrm{~m}, 2 \mathrm{H}), 3.78$ (app. q, 2H, $J$ $=6.3) 3.49$ (quint., $1 \mathrm{H}, J=4.4,8.1) 2.48(\mathrm{~m}, 1 \mathrm{H}), 1.65(\mathrm{~m}, 2 \mathrm{H}), 1.06(\mathrm{~m}, 24 \mathrm{H}) \mathrm{ppm} ;{ }^{13} \mathrm{C}$ NMR (125 MHz, $\left.\mathrm{CDCl}_{3}\right) \delta 140.8,135.5,116.3,114.5,79.2,71.1,60.1,40.5,34.3,18.0$, 14.6, 12.0 ppm; IR (neat) 3080, 2943, 1640, 1463, 1099, $916 \mathrm{~cm}^{-1}$; HRMS (EI) calcd for $\mathrm{C}_{16} \mathrm{H}_{31} \mathrm{O}_{2} \mathrm{Si}[\mathrm{M}-i \mathrm{Pr}]^{+}$283.2093; found 283.2093.

$\widehat{C}_{\mathrm{Me}}{ }^{\mathrm{O}}{ }^{\mathrm{OTIPS}}$

Dihydropyran 14. A solution of allyl ether $13(2.50 \mathrm{~g}, 7.65 \mathrm{mmol})$ in toluene (38.3 $\mathrm{mL})$ was sparged with argon for $15 \mathrm{~min}$. Then Grubb's first generation catalyst $(0.504 \mathrm{~g}$, $0.612 \mathrm{mmol}$ ) was introduced into the reaction vessel in one portion. The purple solution gradually turned light brown. The solution was stirred at $21^{\circ} \mathrm{C}$ for $2 \mathrm{hr}$, concentrated under reduced pressure, and the brown residue was purified by silica gel chromatography (6\% $\mathrm{Et}_{2} \mathrm{O} /$ Hexanes) to give $1.86 \mathrm{~g}$ ( $81 \%$ yield) of the title compound as a colorless oil: $\mathrm{R}_{\mathrm{f}}$ $=0.49\left(6 \% \mathrm{Et}_{2} \mathrm{O} / \mathrm{Hexanes}\right) ;[\alpha]_{\mathrm{D}}+52.7\left(c\right.$ $\left.2.83, \mathrm{CHCl}_{3}\right) ;{ }^{1} \mathrm{H} \mathrm{NMR}\left(500 \mathrm{MHz}, \mathrm{CDCl}_{3}\right) \delta$ $5.70(\mathrm{tdd}, 1 \mathrm{H}, J=2.1,3.3,10.2), 5.60(\mathrm{dq}, 1 \mathrm{H}, J=2.0,10.2), 4.14-4.05(\mathrm{~m}, 2 \mathrm{H}), 3.89-$ 
1657, 1463, 1244, $1097 \mathrm{~cm}^{-1}$; HRMS (EI) calcd for $\mathrm{C}_{17} \mathrm{H}_{33} \mathrm{O}_{2} \mathrm{Si}[\mathrm{M} \mathrm{-} \mathrm{H}]^{+}$297.2250; found 297.2256 .

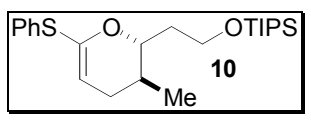

Hemithio ketene acetal 10. Dihydropyran 15 (0.100 g, $0.335 \mathrm{mmol})$ was dissolved in $0.33 \mathrm{~mL}$ of $\mathrm{THF}$, the solution was cooled to $-78{ }^{\circ} \mathrm{C}$, and then $t$-BuLi (1.5 $\mathrm{M}$ in pentane, $0.89 \mathrm{~mL}, 1.34 \mathrm{mmol}$ ) was added to the stirring solution dropwise over a $10 \mathrm{~min}$ period. The reaction mixture, comprised of a bright yellow solution and a fine white suspension, was stirred at $-78{ }^{\circ} \mathrm{C}$ for $15 \mathrm{~min}$, warmed to $0{ }^{\circ} \mathrm{C}$ and stirred for another $2 \mathrm{hr}$. The now pale yellow solution was cooled to $-78{ }^{\circ} \mathrm{C}$, and a solution of phenyl disulfide $(0.292 \mathrm{~g}$, $1.34 \mathrm{mmol})$ in THF $(2.68 \mathrm{~mL})$ was added dropwise over a $10 \min$ period. The pale yellow solution was stirred at $-78{ }^{\circ} \mathrm{C}$ for $2 \mathrm{hr}$, warmed to room temperature, and diluted with $10 \mathrm{~mL}$ of water. The mixture was extracted with hexanes $(3 \times 20 \mathrm{~mL})$, the combined organic layers were washed with brine $(1 \times 20 \mathrm{~mL})$, dried over anhydrous $\mathrm{MgSO}_{4}$, filtered, and concentrated under reduced pressure. The residue was purified by flash chromatography (deactivated silica gel, 100\% Hexanes) to give $0.111 \mathrm{~g}$ (82\% yield) of the title compound as a colorless oil: $\mathrm{R}_{\mathrm{f}}=0.52\left(2 \% \mathrm{Et}_{2} \mathrm{O} /\right.$ Pentane $) ;[\alpha]_{\mathrm{D}}+62.3(c$ 0.840, $\left.\mathrm{CH}_{2} \mathrm{Cl}_{2}\right) ;{ }^{1} \mathrm{H}$ NMR (500 MHz, $\left.\mathrm{C}_{6} \mathrm{D}_{6}\right) \delta 7.43(\mathrm{dd}, 2 \mathrm{H}, J=1.2,7.4), 7.07(\mathrm{t}, 2 \mathrm{H}, J=$ 7.4), $6.96(\mathrm{~m}, 1 \mathrm{H}), 5.24(\mathrm{dd}, 1 \mathrm{H}, \mathrm{J}=2.8,4.5), 3.65(\mathrm{~m}, 3 \mathrm{H}), 1.85-1.75(\mathrm{~m}, 2 \mathrm{H}), 1.69-$ $1.62(\mathrm{~m}, 1 \mathrm{H}), 1.52-1.48(\mathrm{~m}, 2 \mathrm{H}), 1.07(\mathrm{~m}, 21 \mathrm{H}), 0.68(\mathrm{~d}, 3 \mathrm{H}, J=6.3) \mathrm{ppm} ;{ }^{13} \mathrm{C} \mathrm{NMR}$ (125 MHz, $\left.\mathrm{C}_{6} \mathrm{D}_{6}\right) \delta 147.1,135.8,130.4,129.4,126.9,107.6,80.3,60.4,36.4,31.3,30.9$, 18.6, 17.9, 12.6 ppm; IR (neat) 3060, 2943, 1633, 1584, 1463, $1068 \mathrm{~cm}^{-1}$; HRMS (ESI) calcd for $\mathrm{C}_{23} \mathrm{H}_{38} \mathrm{O}_{2} \mathrm{SSiNa}[\mathrm{M}+\mathrm{Na}]^{+}$429.2260; found 499.2259. 


$\underbrace{\mathrm{OH}}_{M e} 18$

Homoallylic alcohol 18. Alcohol 18 was synthesized by adopting a procedure developed by Ardisson et al; Ardisson, J.; Berque, I.; Brion, J. -D.; Férézou, J. -P.; Le Ménéz, P.; Mahuteau, J.; Pancrazi, A.; Razon, P. J. Org. Chem. 1999, 64, 373-381. The spectal data of homoallylic alcohol $\mathbf{1 8}$ matched what was reported by Hall et al.; Gravel, M.; Hall, D. G.; Lachance, H.; Lu, X. J. Am. Chem. Soc. 2003, 125, 10160-10161.

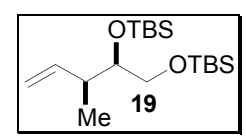

Alkene 19. A solution of alcohol $18(2.50 \mathrm{~g}, 10.8 \mathrm{mmol})$, imidazole (0.886 g, 13.0 mmol), and DMAP $(0.132 \mathrm{~g}, 1.08 \mathrm{mmol})$ in DMF $(21.7 \mathrm{~mL})$ was cooled to $0{ }^{\circ} \mathrm{C}$. $\mathrm{TBSCl}$ (1.80 $\mathrm{g}, 11.9)$ was then added to the reaction mixture, and the resulting solution was stirred at $0{ }^{\circ} \mathrm{C}$ for $30 \mathrm{~min}$, warmed to room temperature, and stirred for an additional 18 hr. A solution of saturated $\mathrm{NaHCO}_{3(\mathrm{aq})}(20 \mathrm{~mL})$ was introduced to the reaction mixture and the mixture was extracted with hexanes $(2 \times 150 \mathrm{~mL})$. The combined organic layers were washed with brine $(2 \times 20 \mathrm{~mL})$ dried over anhydrous $\mathrm{MgSO}_{4}$, filtered, and concentrated under reduced pressure. The residue was purified by silica gel chromatography (100\% hexanes) to afford $3.56 \mathrm{~g}$ (95\% yield) of the desired product as a colorless oil: $\mathrm{R}_{\mathrm{f}}=0.51(100 \%$ Hexanes $) ;[\alpha]_{\mathrm{D}}-4.3\left(c \quad 0.54, \mathrm{CHCl}_{3}\right) ;{ }^{1} \mathrm{H} \mathrm{NMR}(500 \mathrm{MHz}$, $\left.\mathrm{CDCl}_{3}\right) \delta 5.87(\mathrm{ddd}, 1 \mathrm{H}, J=7.3,10.4,16.4), 5.00(\mathrm{~m}, 2 \mathrm{H}), 3.62(\mathrm{~m}, 1 \mathrm{H}), 3.52(\mathrm{~m}, 2 \mathrm{H})$, $2.40(\mathrm{~m}, 1 \mathrm{H}), 1.00(\mathrm{~d}, 3 \mathrm{H}, J=6.9), 0.91(\mathrm{~m}, 18 \mathrm{H}), 0.07(\mathrm{~m}, 12 \mathrm{H}) \mathrm{ppm} ;{ }^{13} \mathrm{C}$ NMR $(125$ $\left.\mathrm{MHz}, \mathrm{CDCl}_{3}\right) \delta 142.3,113.7,76.6,65.4,40.4,26.0,18.4,18.2,13.6,-4.1,-4.7,-5.3,-5.4$ ppm; IR (neat) 3080, 2930, 1472, 1463, 1255, $1093 \mathrm{~cm}^{-1}$; HRMS (ESI) calcd for $\mathrm{C}_{18} \mathrm{H}_{40} \mathrm{O}_{2} \mathrm{Si}_{2} \mathrm{Na}[\mathrm{M}+\mathrm{Na}]^{+}$367.2465; found 367.2453. 


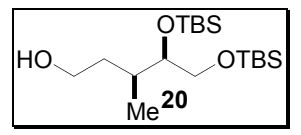

Alcohol 20. To a solution of alkene $19(2.80 \mathrm{~g}, 8.12 \mathrm{mmol})$ in THF $(2.80 \mathrm{~mL})$, precooled to $0{ }^{\circ} \mathrm{C}$, was added $\mathrm{BH}_{3}(1 \mathrm{M}$ solution in THF, $12.2 \mathrm{~mL}, 12.2 \mathrm{mmol})$. The solution was allowed to warm to room temperature and stirred for $7 \mathrm{hr}$ then recooled to 0 ${ }^{\circ} \mathrm{C}$. A solution of $\mathrm{NaOH}_{(\mathrm{aq})}(2.5 \mathrm{M}, 14 \mathrm{~mL})$ was then added dropwise over a 15 min period, followed by the dropwise addition of $30 \%$ aqueous $\mathrm{H}_{2} \mathrm{O}_{2}(7 \mathrm{~mL})$, the resulting mixture was warmed to room temperature and stirred for one hour. The aqueous layer was extracted with $\mathrm{Et}_{2} \mathrm{O}(2 \times 100 \mathrm{~mL})$, washed with brine, dried over anhydrous $\mathrm{MgSO}_{4}$, filtered, and concentrated under reduced pressure. The residue was purified by silica gel chromatography (gradient column, 10\% then 15\% EtOAc/Hexanes) to afford $2.71 \mathrm{~g}$ (92\% yield) of the desired product as a colorless oil: $\mathrm{R}_{\mathrm{f}}=0.36(10 \%$ EtOAc/Hexanes); $[\alpha]_{\mathrm{D}}+2.8\left(c 0.61, \mathrm{CHCl}_{3}\right) ;{ }^{1} \mathrm{H} \mathrm{NMR}\left(500 \mathrm{MHz}, \mathrm{CDCl}_{3}\right) \delta 3.73-3.60(\mathrm{~m}, 3 \mathrm{H}), 3.56(\mathrm{~m}$, 2H), $2.25(\mathrm{~m}, 1 \mathrm{H}), 1.84(\mathrm{qd}, 1 \mathrm{H}, \mathrm{J}=2.8,4.2), 1.66(\mathrm{~m}, 1 \mathrm{H}), 1.46(\mathrm{~m}, 1 \mathrm{H}), 0.09(\mathrm{~m}, 21 \mathrm{H})$, $0.07(\mathrm{~m}, 12 \mathrm{H}) \mathrm{ppm} ;{ }^{13} \mathrm{C} \mathrm{NMR}\left(125 \mathrm{MHz}, \mathrm{CDCl}_{3}\right) \delta 76.8,64.9,61.7,36.5,34.3,26.0$, $25.9,18.4,18.1,15.4,-4.2,-4.9,-5.3,-5.4$ ppm; IR (neat) 3349, 2930, 1472, 1245, 1110 , $836 \mathrm{~cm}^{-1}$; HRMS (ESI) calcd for $\mathrm{C}_{18} \mathrm{H}_{42} \mathrm{O}_{3} \mathrm{Si}_{2} \mathrm{Na}[\mathrm{M}+\mathrm{Na}]^{+}$385.2570; found 385.2557.

OTBS

Chloride 21. Alcohol 20 (1.90 g, $5.24 \mathrm{mmol})$ was dissolved in 1:1 MeCN:Pyridine (26.2 mL). To this solution was added $\mathrm{CCl}_{4}(5.04 \mathrm{~mL}, 52.4 \mathrm{mmol}), \mathrm{PPh}_{3}(2.75 \mathrm{~g}, 10.5$ $\mathrm{mmol}$ ), the solution was allowed to stir at room temperature for one hour, then heated to $50{ }^{\circ} \mathrm{C}$ for five hours. The dark brown mixture was cooled to room temperature, diluted with $20 \mathrm{~mL}$ of saturated $\mathrm{NaHCO}_{3(\mathrm{aq})}$ and extracted with $\mathrm{Et}_{2} \mathrm{O}(2$ x $100 \mathrm{~mL})$. The 
combined organic layers were washed with brine $(2 \times 20 \mathrm{~mL})$, dried over anhydrous $\mathrm{MgSO}_{4}$, filtered, and concentrated under reduced pressure. The residue was purified by silica gel chromatography ( $3 \%$ EtOAc/Hexanes) to give $1.86 \mathrm{~g}$ (93\% yield) of the desired product as a colorless oil: $\mathrm{R}_{\mathrm{f}}=0.81(4 \%$ EtOAc/Hexanes $) ;[\alpha]_{\mathrm{D}}+0.9\left(c 1.8, \mathrm{CHCl}_{3}\right) ;{ }^{1} \mathrm{H}$ NMR (500 MHz, $\left.\mathrm{CDCl}_{3}\right) \delta 3.65-3.47(\mathrm{~m}, 5 \mathrm{H}), 1.97-1.86(\mathrm{~m}, 2 \mathrm{H}), 1.67(\mathrm{~m}, 1 \mathrm{H}), 0.90(\mathrm{~s}$, 9H), 0.89 (s, 9H), $0.86(\mathrm{~d}, 3 \mathrm{H}, J=6.8), 0.06(\mathrm{~m}, 12 \mathrm{H}) \mathrm{ppm} ;{ }^{13} \mathrm{C} \mathrm{NMR}\left(125 \mathrm{MHz}, \mathrm{CDCl}_{3}\right)$ $\delta$ 75.6, 64.9, 43.6, 36.7, 33.0, 26.0, 25.9, 18.3, 18.1, 12.7, -4.0, -4.9, -5.3, -5.4 ppm; IR (neat) $2931,1470,1389,1254,1097,836 \mathrm{~cm}^{-1}$; HRMS (ESI) calcd for $\mathrm{C}_{18} \mathrm{H}_{41} \mathrm{ClO}_{2} \mathrm{Si}_{2} \mathrm{Na}$ $[\mathrm{M}+\mathrm{Na}]^{+}$381.2412; found 381.2401.



Diol 11. To a solution of chloride $21(0.250 \mathrm{~g}, 0.656 \mathrm{mmol})$ in $\mathrm{MeOH}(6.6 \mathrm{~mL})$ was added $\mathrm{MeSO}_{3} \mathrm{H}(0.17 \mathrm{~mL}, 2.62 \mathrm{mmol})$. The reaction mixture was stirred at room temperature for $2.5 \mathrm{hrs}$, diluted with $20 \mathrm{~mL}$ of saturated $\mathrm{NaHCO}_{3(\mathrm{aq})}$, and extracted with EtOAc $(3 \times 60 \mathrm{~mL})$. The organic phase was dried over anhydrous $\mathrm{MgSO}_{4}$, filtered, and concentrated under reduced pressure. The yellow residue was purified by silica gel chromatography $\left(70 \% \mathrm{EtOAc} / \mathrm{CH}_{2} \mathrm{Cl}_{2}\right)$ to give $0.0905 \mathrm{~g}$ (90\% yield) of the desired diol 11 as a light yellow oil: $\mathrm{R}_{\mathrm{f}}=0.39\left(70 \% \mathrm{EtOAc} / \mathrm{CH}_{2} \mathrm{Cl}_{2}\right) ;[\alpha]_{\mathrm{D}}-21.8\left(\right.$ c 3.27, $\left.\mathrm{CHCl}_{3}\right) ;{ }^{1} \mathrm{H}$ NMR (500 MHz, $\left.\mathrm{CDCl}_{3}\right) \delta 3.66(\mathrm{~m}, 3 \mathrm{H}), 3.58$ (m, 2H), 2.27 (brs, 2H), $1.95(\mathrm{~m}, 1 \mathrm{H}), 1.87$ $(\mathrm{m}, 1 \mathrm{H}), 1.61(\mathrm{~m}, 1 \mathrm{H}), 0.95(\mathrm{~d}, 3 \mathrm{H}, J=6.8) \mathrm{ppm} ;{ }^{13} \mathrm{C} \mathrm{NMR}\left(125 \mathrm{MHz}, \mathrm{CDCl}_{3}\right) \delta 74.8$, 64.9, 43.1, 35.9, 33.0, 13.7 ppm; IR (neat) 3368, 2965, 1460, 1294, 1066, $657 \mathrm{~cm}^{-1}$; HRMS (ESI) calcd for $\mathrm{C}_{6} \mathrm{H}_{13} \mathrm{ClO}_{2} \mathrm{Na}[\mathrm{M}+\mathrm{Na}]^{+}$175.0502; found 175.0499.

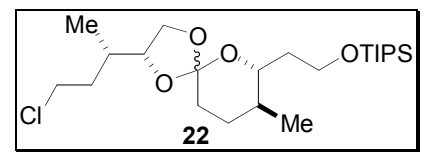


Ortho ester 22. Hemithio ketene acetal $10(70 \mathrm{mg}, 0.17 \mathrm{mmol})$ was dissolved in benzene ( $1 \mathrm{~mL})$, concentrated under reduced pressure (to azeotrope any residual water), and then dissolved in $\mathrm{CH}_{2} \mathrm{Cl}_{2}(1.7 \mathrm{~mL})$. To this solution was added a solution of diol $\mathbf{1 1}$ (32 $\mathrm{mg}, 0.21 \mathrm{mmol})$ in $1.0 \mathrm{~mL}$ of $\mathrm{CH}_{2} \mathrm{Cl}_{2}$, then $\mathrm{CSA}(0.4 \mathrm{mg}, 0.002 \mathrm{mmol})$. The reaction mixture was stirred for $15 \mathrm{~min}$ at room temperature, then warmed to $40{ }^{\circ} \mathrm{C}$ and stirred at this temperature for $1 \mathrm{hr}$. The mixture was cooled to room temperature, treated with 0.2 $\mathrm{mL}$ of $\mathrm{Et}_{3} \mathrm{~N}$, and concentrated under reduced pressure. The resulting residue was purified by silica gel chromatography ( $8 \%$ EtOAc/Hexanes) to give $60 \mathrm{mg}(77 \%$ yield) of the desired product as a 1.5:1 mixture comprised of two major orthoesters $(\sim 95 \%)$ that are epimeric at the spiro center. The mixture was characterized: $R_{f}=0.42(8 \%$ EtOAc/Hexanes); ${ }^{1} \mathrm{H}$ NMR (500 MHz, $\left.\mathrm{CDCl}_{3}\right) \delta$ 4.21-4.10 (m, 1.5H), 4.04-3.88 (m, $1.2 \mathrm{H}), 3.84-3.50(\mathrm{~m}, 8.0 \mathrm{H}), 1.97-1.35(\mathrm{~m}, 13 \mathrm{H}), 1.06(\mathrm{~m}, 31.6 \mathrm{H}), 0.94(\mathrm{~d}, 3 \mathrm{H}, J=6.7)$, $0.85(\mathrm{~m}, 3.9 \mathrm{H}) \mathrm{ppm} ;{ }^{13} \mathrm{C} \mathrm{NMR}\left(125 \mathrm{MHz}, \mathrm{CDCl}_{3}\right) \delta 119.3,119.2,81.0,77.6,76.3,76.0$, 67.0, 66.2, 60.1, 59.7, 42.8, 42.6, 36.3, 36.2, 35.6, 35.3, 34.4, 34.3, 34.1, 33.3, 33.2, 31.7, $30.6,18.03,18.01,17.9,17.1,17.0,15.1,14.1,12.0 \mathrm{ppm}$; IR (neat) 2942, 1462, 1381, 1243, 1096, $1066 \mathrm{~cm}^{-1}$; HRMS (ESI) calcd for $\mathrm{C}_{23} \mathrm{H}_{46} \mathrm{ClO}_{4} \mathrm{Si}[\mathrm{M}+\mathrm{H}]^{+}$449.2854; found 449.2863.

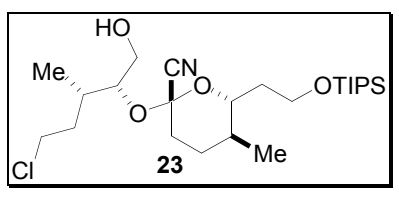

Cyano acetal 23 and 24. A solution of orthoester 22 (55 mg, $0.12 \mathrm{mmol})$, TMSCN (0.017 mL, $0.13 \mathrm{mmol})$, in dichloromethane $(2.4 \mathrm{~mL})$ was cooled to $-78{ }^{\circ} \mathrm{C}$, and then $\mathrm{BF}_{3} \cdot \mathrm{Et}_{2} \mathrm{O}(0.17 \mathrm{~mL}, 0.13 \mathrm{mmol})$ was added to the reaction vessel. The resulting solution was allowed to stir at $-78{ }^{\circ} \mathrm{C}$ for $16 \mathrm{hr}$, then an aqueous solution of $\mathrm{K}_{2} \mathrm{CO}_{3}(1 \mathrm{M}, 1 \mathrm{~mL})$ 
was added, and the mixture was allowed to warm to $0{ }^{\circ} \mathrm{C}$. The mixture was diluted with saturated $\mathrm{NaHCO}_{3(\mathrm{aq})}(20 \mathrm{~mL})$, extracted with $\mathrm{Et}_{2} \mathrm{O}(2 \times 50 \mathrm{~mL})$, washed with $20 \mathrm{~mL}$ of brine, dried over anhydrous $\mathrm{MgSO}_{4}$, filtered, and concentrated under reduced pressure. The residue was purified by silica gel chromatography (15\% EtOAc/Hexanes) to give 42 mg (72\% yield) of a $6: 1$ mixture of cyano acetals $\mathbf{2 3}$ and $\mathbf{2 4}$ as a colorless oil. The major cyano acetal 23 was separated by silica gel chromatography and characterized: $R_{\mathrm{f}}=0.49$ $\left(15 \%\right.$ EtOAc/Hexanes); $[\alpha]_{\mathrm{D}}+30.1\left(\right.$ c $\left.0.725, \mathrm{CHCl}_{3}\right) ;{ }^{1} \mathrm{H} \mathrm{NMR}\left(500 \mathrm{MHz}, \mathrm{CDCl}_{3}\right) \delta 4.04$ (ddd, 1H, $J=2.8,4.3,7.1), 3.86-3.74(\mathrm{~m}, 3 \mathrm{H}), 3.68-3.54(\mathrm{~m}, 4 \mathrm{H}), 2.14(\mathrm{~m}, 2 \mathrm{H}), 2.03$ $(\mathrm{m}, 2 \mathrm{H}), 1.88(\mathrm{dq}, 1 \mathrm{H}, J=3.7,13.8), 1.78(\mathrm{dt}, 1 \mathrm{H}, J=4.2,13.4), 1.66-1.53(\mathrm{~m}, 3 \mathrm{H}), 1.49$ $(\mathrm{m}, 1 \mathrm{H}), 1.08(\mathrm{~m}, 21 \mathrm{H}), 0.98(\mathrm{~d}, 3 \mathrm{H}, J=7.0), 0.93(\mathrm{~d}, 3 \mathrm{H}, J=6.5) \mathrm{ppm} ;{ }^{13} \mathrm{C} \mathrm{NMR}(125$ $\left.\mathrm{MHz}_{,} \mathrm{CDCl}_{3}\right) \delta 115.8,97.5,83.7,79.1,62.8,58.6,43.0,35.9,35.2,33.7,33.2,29.5$, 18.0, 17.0, 14.9, 11.9 ppm; IR (neat) 3512, 2941, 1461, 1074, 882, $681 \mathrm{~cm}^{-1}$; HRMS (ESI) calcd for $\mathrm{C}_{24} \mathrm{H}_{46} \mathrm{ClNO}_{4} \mathrm{SiNa}[\mathrm{M}+\mathrm{Na}]^{+}$498.2782; found 498.2772.

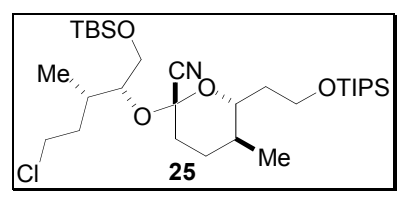

Cyano acetal 25. Cyano acetal $23(27 \mathrm{mg}, 0.057 \mathrm{mmol})$ was dissolved in DMF (1.1 $\mathrm{mL}$ ). To this solution was added in sequence imidazole (39 mg, $0.57 \mathrm{mmol}$ ), DMAP (14 $\mathrm{mg}, 0.11 \mathrm{mmol})$, and $\mathrm{TBSCl}(43 \mathrm{mg}, 0.28 \mathrm{mmol})$. The solution was allowed to stir at room temperature for $18 \mathrm{hr}$, then an aqueous solution of $\mathrm{K}_{2} \mathrm{CO}_{3}(1 \mathrm{M}, 1 \mathrm{~mL})$, followed by $10 \mathrm{~mL}$ of $\mathrm{H}_{2} \mathrm{O}$ were added to the reaction vessel. The mixture was extracted with hexanes $(2 \times 50 \mathrm{~mL})$, washed with $20 \mathrm{~mL}$ of brine, dried over anhydrous $\mathrm{MgSO}_{4}$, filtered, and concentrated under reduced pressure to give an oil that was purified by silica gel chromatography (6\% EtOAc/Hexanes) to afford $30 \mathrm{mg}$ (91\% yield) of cyano acetal 25 as 
a colorless oil: $\mathrm{R}_{\mathrm{f}}=0.51(6 \%$ EtOAc/Hexanes $) ;[\alpha]_{\mathrm{D}}+54\left(c\right.$ 0.65, $\left.\mathrm{CHCl}_{3}\right) ;{ }^{1} \mathrm{H}$ NMR $(500$ $\left.\mathrm{MHz}, \mathrm{CDCl}_{3}\right) \delta 3.92$ (quint, $\left.1 \mathrm{H}, J=4.0,7.8\right), 3.82(\mathrm{~m}, 3 \mathrm{H}), 3.70-3.58(\mathrm{~m}, 4 \mathrm{H}), 2.27(\mathrm{~m}$, 1H), $2.06(\mathrm{~m}, 2 \mathrm{H}), 1.98(\mathrm{~m}, 1 \mathrm{H}), 1.82(\mathrm{~m}, 1 \mathrm{H}), 1.76-1.62(\mathrm{~m}, 3 \mathrm{H}), 1.57-1.38(\mathrm{~m}, 2 \mathrm{H})$, $1.08(\mathrm{~m}, 21 \mathrm{H}), 0.95(\mathrm{~d}, 3 \mathrm{H}, J=7.0), 0.91(\mathrm{~d}, 3 \mathrm{H}, J=6.4), 0.89(\mathrm{~s}, 9 \mathrm{H}), 0.04(\mathrm{~m}, 6 \mathrm{H})$ ppm; ${ }^{13} \mathrm{C}$ NMR $\left(125 \mathrm{MHz}, \mathrm{CDCl}_{3}\right) \delta$ 116.7, 98.8, 80.6, 78.3, 63.0, 59.1, 43.4, 36.1, 35.9, $35.8,33.7,31.0,29.5,25.8,18.2,18.1,17.1,13.4,12.0,-5.4,-5.5$ ppm; IR (neat) 2929, 2226, 1462, 1385, 1254, $1113 \mathrm{~cm}^{-1}$; HRMS (ESI) calcd for $\mathrm{C}_{30} \mathrm{H}_{60} \mathrm{ClNO}_{4} \mathrm{Si}_{2} \mathrm{Na}[\mathrm{M}+$ $\mathrm{Na}]^{+}$612.3447; found 612.3446 .

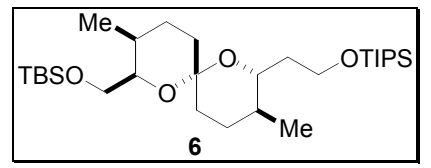

Spirofungin B core 6. Compound 25 was dissolved in THF $(0.22 \mathrm{~mL})$, and to this solution was added $0.1 \mathrm{mg}$ of 1,10 -phenanthroline. The solution was cooled to $-78{ }^{\circ} \mathrm{C}$, and titrated with $n$-BuLi (1.6 M in hexanes) (in order to remove any trace of moisture) until a brown-red endpoint persisted. A freshly prepared solution of LiDBB (ca. $0.4 \mathrm{M}$, $0.14 \mathrm{~mL}, 0.055 \mathrm{mmol}$ ) was introduced into the reaction vessel at $-78^{\circ} \mathrm{C}$, dropwise over a $7 \mathrm{~min}$ period. The solution was allowed to stir at $-78{ }^{\circ} \mathrm{C}$ for $30 \mathrm{~min}$, and then $1 \mathrm{~mL}$ of $\mathrm{MeOH}$ was added to the reaction mixture followed by $10 \mathrm{~mL}$ of water. The aqueous phase was extracted with $\mathrm{Et}_{2} \mathrm{O}(2 \times 20 \mathrm{~mL})$, the combined organic layers were dried over anhydrous $\mathrm{Na}_{2} \mathrm{SO}_{4}$, filtered, and concentrated under reduced pressure to give a residue that was purified by silica gel chromatography (6\% EtOAc/Hexanes) to afford $11 \mathrm{mg}$ (92\% yield) of spiroacetal 6 as a colorless oil: $\mathrm{R}_{\mathrm{f}}=0.50$ (6\% EtOAc/Hexanes); $[\alpha]_{\mathrm{D}}+14$ (c 0.05, $\mathrm{CH}_{2} \mathrm{Cl}_{2}$ ); ${ }^{1} \mathrm{H}$ NMR (500 MHz, $\left.\mathrm{C}_{6} \mathrm{D}_{6}\right) \delta 4.54$ (ddd, $\left.1 \mathrm{H}, J=2.7,6.0,8.5\right), 4.03$ (td, $1 \mathrm{H}, J=6.1,9.4), 3.95(\mathrm{ddd}, 1 \mathrm{H}, J=4.1,7.2,9.9), 3.80(\mathrm{dd}, 1 \mathrm{H}, J=6.0,10.0), 3.65(\mathrm{dd}$, 
$1 \mathrm{H}, J=8.1,10.0), 3.22(\mathrm{td}, 1 \mathrm{H}, J=2.3,9.6), 2.08(\mathrm{qt}, 1 \mathrm{H}, J=4.3,13.6), 2.03-1.93(\mathrm{~m}$, 2H), $1.89(\mathrm{~m}, 1 \mathrm{H}), 1.78-1.68(\mathrm{~m}, 2 \mathrm{H}), 1.60(\mathrm{dt}, 1 \mathrm{H}, J=3.9,13.0), 1.44(\mathrm{~m}, 1 \mathrm{H}), 1.38-$ $1.27(\mathrm{~m}, 4 \mathrm{H}), 1.17(\mathrm{~m}, 21 \mathrm{H}), 1.03(\mathrm{~d}, 3 \mathrm{H}, J=6.9), 0.99(\mathrm{~s}, 9 \mathrm{H}), 0.69(\mathrm{~d}, 3 \mathrm{H}, J=6.6)$, 0.09 (s, 3H), 0.07 (s, 3H) ppm; ${ }^{13} \mathrm{C}$ NMR $\left(125 \mathrm{MHz}, \mathrm{C}_{6} \mathrm{D}_{6}\right) \delta$ 97.7, 75.2, 72.6, 64.6, 61.0, $38.0,37.1,35.7,30.0,28.2,26.7,26.5,23.9,18.8,18.7,17.9,12.8,11.5,-4.6,-5.0$ ppm; IR (neat) 2951, 1462, 1252, 1098, 838, $681 \mathrm{~cm}^{-1}$; HRMS (ESI) calcd for $\mathrm{C}_{29} \mathrm{H}_{60} \mathrm{O}_{4} \mathrm{Si}_{2} \mathrm{Na}$ $[\mathrm{M}+\mathrm{Na}]^{+}$551.3928; found 551.3929. 



$\begin{array}{r}-128.68 \\ -128.58 \\ \hline\end{array}$ 


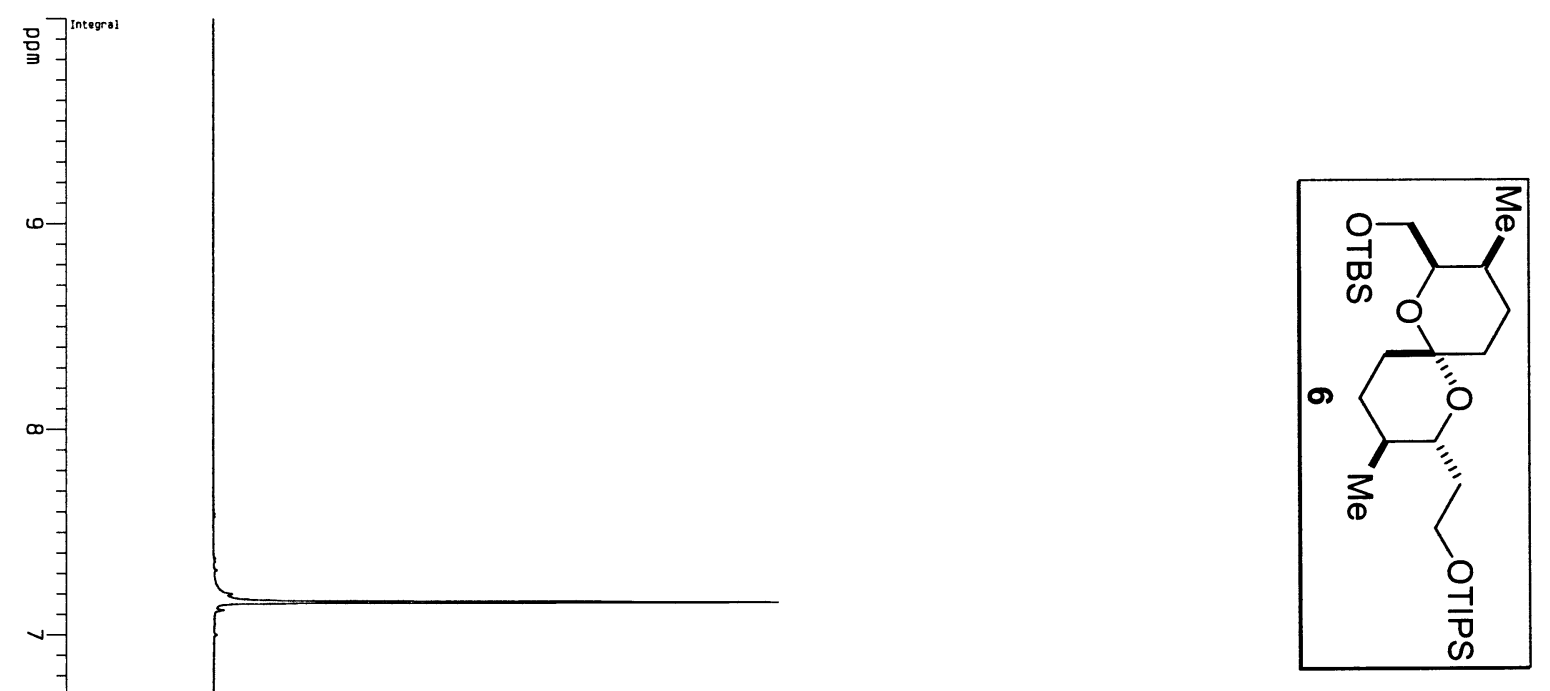

